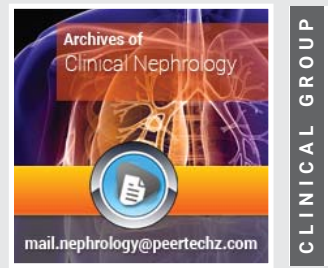

\title{
Microbiological culture results and antibiotic sensitivity in renal preservation solution
}

Received: 24 April, 2020

Accepted: 18 June, 2020

Published: 19 June, 2020

*Corresponding author: Gülay Oyur Çelik, Department of Surgical Nursing, Izmir Katip Çelebi University Faculty of Health Sciences, Izmir, Turkey,

E-mail: gulayoyur@gmail.com

https://www.peertechz.com

Check for updates

\section{Mehmet Fatih Yüzbaşıoğlu', Hatice Güzel ${ }^{2}$, Gülay Oyur Çelik ${ }^{3 *}$, Arzu Tuna ${ }^{2}$, Necla Benlier ${ }^{2}$, Sezgin Topuz ${ }^{1}$, Onur \\ Peker $^{4}$ and Alper Boz ${ }^{5}$}

'Department of General Surgery, Faculty of Medicine, Kahramanmaraş Sütçü İmam University, Kahramanmaraş, Turkey

${ }^{2}$ Internal Medicine Nursing, Faculty of Health Sciences, SANKO University, Gaziantep, Turkey

${ }^{3}$ Department of Surgical Nursing, Izmir Katip Çelebi University Faculty of Health Sciences, İzmir, Turkey ${ }^{4}$ Department of General Surgery, Ministry of Health Çine Hospital, Aydın Turkey

${ }^{5}$ Department of General Surgery, Yucelen Hospital, Mugla, Turkey

\section{Abstract}

Aim/Background: The aim of this study is to investigate the effects of the solutions used to preserve kidney during transplant surgeries on microbiological culture results and antimicrobial resistance and to evaluate this process from the perspectives of recipients and donors.

Methods: This study is a retrospective one, and its data were collected from the files of the transplant patients between October 2009 and June 2018 . In order to identify the bacteria, the results of the bacteria cultivation conducted through standard methods were included. Gram-negative bacteria were also included in the study. The antimicrobial susceptibility of the identified bacteria was analysed by means of the disk diffusion method. Only one preservation solution was taken, and the isolated agent was determined to be staphylococcus.

Results: When all the results were examined, none of the patient had an infection agent causing clinical infection. This result might be related to the fact that cephalosporin treatment was applied for seven days in all the transplant cases in our clinic.

Conclusion: If a good treatment is supported by culture antibiogram, it does not create a problem for the recipient and a successful organ transplant surgery can be performed. In this way, there will be no loss of patients in cases where there are not many organ sources.

\section{Introduction}

Kidney transplant is significant in the treatment of endstage renal disease, and it is one of the most important treatment methods in our age. Transplant surgery is very significant in our country as it is in other parts of the world. However, the basic problem in our country is the low number of organs obtained from cadaveric donors. Success in transplant surgeries has substantially increased thanks to technological progress, developments and changes in immunosuppressive drugs used for organ rejections, new practices in organ preservation and new organ transplant centres in many countries. In transplant surgeries, the increase in the number of cadaveric donors and the development of different methods in organ and tissue preservation, new perfusion systems and new solutions have led to successful outcomes. The extraction, preservation and transportation of organs might result in changes in the organ's internal structure. Ischemia and hypothermia are the most important factors in the preservation of organs after extraction [1]. Various solutions are used in order to preserve the organ and to wash the extracted organ. Initially, the Ringer Lactate solution was used. Then, the Euro-Collins, the Ross-Marshall, 
the University of Wisconsin (UW) and the Celsior and Kyoto solutions were extensively used. Each solution has a difference structure and content; however, each solution has the same objective: to prevent cell oedema, to delay cell destruction, and then to provide the best organ function. Preservatives like Bactrim have been added to some solutions in order to preserve organ and tissue and to prevent infection. Particularly in simple hypothermic preservation, the extracted organ is washed with cold preservative solution $(+40 \mathrm{C})$ and placed in a sterile nylon bag. This sterile bag can be put into a second bag with crushed ice particles, and the extracted organ can be preserved. The most significant advantage of this method is that it is cheap, simple and easy to carry the extracted organ [1-4].

For the preservation of organs and tissues, solutions are used through intravenous infusion immediately after the organ is extracted. The organ should be kept in liquid for preservation. When the number of donors is taken into consideration, it is inevitable that the organ should be extracted in a successful way. In the past, when the recipient or the donor had any source of infection, it used to cause many difficulties in organ transplant surgeries [1-4]. The results of some scientific studies reveal that, even if there is infection in the recipient or the donor, this is not an obstacle for a successful transplant surgery as long as antibiotic prophylaxis therapy is performed. In this context, this study aims to investigate the effects of the solutions used to preserve kidney during transplant surgeries on microbiological culture results and antimicrobial resistance and to evaluate this process from the perspectives of recipients and donors [1-4].

\section{Methods}

This study is a retrospective one, and its data were collected from the files of the transplant patients between October 2009 and June 2018. In order to identify the bacteria, the results of the bacteria cultivation conducted through standard methods were included. Gram-negative bacteria were also included in the study. The antimicrobial susceptibility of the identified bacteria was analysed by means of the disk diffusion method. By analysing the microbiological culture results of the donors, whether bacterial reproduction occurred and whether it was transferred to the recipient were investigated. The permission was obtained from the hospital ethical committee.

\section{Results}

Blood, urine, sputum and throat cultures were taken from the donor before the operation. Blood culture from 29 donors, urine culture from 10 donors, sputum culture from 2 donors and throat culture from 13 donors were taken. Among these blood cultures, only $1(\% 3,44)$ had staphylococcus, while 1 $(\% 3,44)$ had streptococcus and $1(\% 3,44)$ had pseudomonas. Only $1(\% 3,44)$ of the urine cultures had enterococcus while 1 of the sputum cultures had Helicobacter. In the throat cultures, 1 had candida, 1 had pseudomonas, whereas $2(\% 6,89)$ had Acinetobacter, $1(\% 3,44)$ had staphylococcus epidermidis and 1 $(\% 3,44)$ had Herpes virus. When these cultures were examined, it was observed that bacterial reproduction occurred in ten donors. In addition, the kidney to be extracted from the donor was washed through renal preservation solutions and kept in liquid. In the cultures taken from the liquids, no bacterial reproduction occurred. When the files of the recipients were analysed, it is clearly observed that any reproduction did not occur in any of the cultures taken after after the surgery, although nine of the donors had the microorganisms that could have caused infection. The fact that infection was not observed in the culture results of the recipients is a significant finding. This might be connected with the fact that the recipients were supported with a good prophylactic therapy method. Cephalosporin therapy is routinely performed for seven days in clinics after transplant surgeries.

\section{Discussion}

The most commonly used renal preservation solutions for kidney transplant surgeries are the Euro-Collins, the University of Wisconsin (UW) and the Bretschneider HTK solutions. In terms of long cold ischemia times, whether the HTC solution or the UW solution is superior has not been demonstrated. As the organ extracted from the living donor should be transplanted immediately, some surgeons prefer to perfuse the kidney with heparinised ringer lactate rather than perfusion fluids. In order to prolong the period and to prevent infection, antibiotic prophylaxis is very significant $[5,6]$. While determining the risk of infection after transplant surgeries, although latent and active infections in the donor or the recipient, operationrelated complications, coexistent diseases like Chronic Obstructive Pulmonary Disease (COPD) and the intensity of immunosuppressive therapy are important, there is a timeline for infections that might occur after transplant surgeries. One month after transplant surgeries, transmitter-induces infections, surgical wound and abdominal infections, central catheter infections and hospital acquired pathogens are quite common. Urinary tract infection is also common in this period. the infection related to our study is urinary tract infection [5-7]. Opportunistic infections between month 1 and month 6 after transplant surgeries should be considered first. Immunosuppressive maintenance therapy is applied intensively during this period, and the effects of induction therapy are still observable. Therefore, the risk of the reactivation of latent pathogens is very high. Cytomegalovirus (CMV), Herpes zoster virus (HSV), Varicella zoster virus (VZV) and BK virus, Pneumocystis pneumonia (PCP), Aspergillus and Nocardia infections are common Herpes virus. As seen in the study, 1 patient had Herpes virus [5-9].

Viral infections are the most common infectious complications of immunosuppressive therapy after solid organ transplant. CMV is the most common viral infection. The status of the recipient and the donor should be defined in the pretransplant evaluation. This definition determines how long prophylaxis therapy should be continued and with which drug prophylaxis therapy should be performed [5-9]. Valganciclovir is used to prevent CMV infection and/or CMV disease. In the pretransplant evaluations, if the recipient and the donor are not CMV (-), valganciclovir and CMV prophylaxis are recommended. In the profiles of patients in Turkey, both the recipient and the donor are CMV (+). The duration of prophylaxis therapy is recommended to be between 3 and 12 months. Although it

Citation: Yüzbaşıoğlu MF, Güzel H, Çelik GO, Tuna A, Benlier N, et al. (2020) Microbiological culture results and antibiotic sensitivity in renal preservation solution. 
changes from centre to centre, the general tendency is to use valganciclovir $450 \mathrm{mg} 1 \times 2$ in the first six months (especially in patients receiving ATG induction). However, in line with the declaration of health practises in Turkey, it can be applied for the first three months after transplant surgeries. The most important side effect is bone marrow suppression. During rejection treatments developed at any time, it is recommended to start prophylactic therapy for at least six weeks [5-9]. Trimethoprim / sulfamethoxazole (8omg tmp / 400mg smx): Antibacterial prophylaxis is recommended for 6 months. In cases where anti-rejection therapy should be given, it should be resumed and continued for at least 6 weeks. Prophylaxis of urinary tract infection is used to prevent opportunistic infections of PCP, Nocardia, Listeria monocytogenesis and Toxoplasma gondii. It is usually well tolerated but might cause bone marrow suppression or renal dysfunction. If the commercially available $160 \mathrm{mg}$ trimethoprim / $800 \mathrm{mg}$ sulfamethoxazole-containing form is used, it is sufficient to give 3 days a week. Bacteraemia in solid organ transplants can lead to life-threatening complications. The incidence of bacteraemia varies between \%8,6-26 depending on the transplanted organ and is seen as the most important cause of morbidity and mortality. This is particularly important in bacteria that develop antibiotic resistance. These groups of microorganisms (Enterococcus faecium, Staphylococcus aure-us, Klebsiella pneumoniae, Acinetobacter baumannii, Pseudomonas aeruginosa and Enterobacter spp.) were grouped as ESCAPE pathogens by the American Society of Infectious Diseases [59].

Pseudomonas infections are considered to be the most lethal factor in this group, and antibiotic resistance is encountered in $50 \%$ of pseudomonas infections detected in transplant patients. Reported source of pseudomonas infection in solid organ transplantations is very rare. In these patients, infection findings usually occur within the first 10 days. In particular, there are reports about the fact that pseudomonas infections developing in respiratory tract enter the systemic circulation via the innominate artery [9-13]. In the early postoperative period, P. aeruginosa infection has been shown to cause pseudoaneurysm and dissociation in artery anastomosis. This usually results in graft or patient loss. The elastase enzyme secreted by bacteria directly causes endothelial cell and basement membrane damage and blood vessel wall bleeding [5-10].

Oral nystatin or mouthwash is used 3 times a day for oral and oesophageal candidiasis prophylaxis. Although it is recommended for 1-3 months in handbooks, many centres in Turkey use it in the first 3-6 months. It is recommended to use it for at least 1 month after antirejection treatments. In cases where fungal infections are common, oral fluconazole $1 \times 100 \mathrm{mg}$ can be given instead of oral nystatin for 3-6 months. According to the results of the study, candida infection was observed only in 1 patient [9-13]. Bacteria, which are thought to be caused by the donor and which are already found in the donor, did not cause any endemia in the recipient due to antibiotic treatment in our clinic routine although fungal infection was observed in our study.
Despite the measures to prevent possible donor-induced infection in solid organ transplantations, a $0.2-6 \%$ infection transition was reported. In addition, at least $5 \%$ of the donors were considered to be bacteriemic during the organ uptake [7-9]. For that reason, in cadaveric donor transplants, it is recommended that donor cultures should routinely be taken in potential donor candidates with a hospital stay longer than three days. In order to reduce risk, it is recommended that the medical and social history of the donor should be taken into account and that a careful physical examination and laboratory screening should be performed. It should be kept in mind that donor blood cultures can reveal secret bacteriemias and that intensive treatment with hemodynamic insta-bil donors might adversely affect laboratory test results due to hemodilution [913].

It is suggested that bacteriemic donors can be used under certain conditions as seen in recent publications. It is recommended that the infected donor should receive antimicrobial therapy for at least $24-48$ hours, that laboratory and clinical response should be considered and that the same antimicrobial therapy should be used for the recipient for 7-14 days. In addition, by means of nonspecific antibacterial and antifungal therapy which would be performed independently of the culture results of kidney transplant surgeries from the infected donors, there are centers reporting highly successful results in graft and patient survival in the first six months [913].

In our country, the frequency of donor-induced infection in cadaveric donor transplantation is unknown. However, the number of patients for transplant is increasing day by day, and the transplantation of cadaveric donors seems to be the most important source to meet this requirement. With the use of necessary microbiological follow-up and treatment facilities, organs from infected donors can also be provided; however, in this case it is necessary to pay attention especially to organisms that have developed antibiotic resistance. Donor-induced Pseudomonas infections are also important due to their high mortality rate in this group [1,5,6,9-13].

\section{Result}

it should be ensured that reproduction occurring in culture results, whether it is from a living donor or from a cadaver, does not affect organ transplants. If a good treatment is supported by culture antibiogram, it does not create a problem for the recipient and a successful organ transplant surgery can be performed. In this way, there will be no loss of patients in cases where there are not many organ sources.

\section{References}

1. Haberal M, Moray M, Gülay H (2010) Böbrek Transplantasyonu, In: Sayek I,ed 'Temel Cerrahi, $4^{\text {th }}$ Edition 4. Ayrıntı Basım Matbaacılık Hiz. San. Tic. Ltd. Şti, Ankara 1: 790-806.

2. Yalın A, Keskinöz EN, Kızaran A (2011) Organ Korunması. Türkiye ACU Sağlık Bil Derg 2: 1-4. Link: https://bit.ly/3fzLDxx

3. Lee CY, Mangino MJ (2009) Preservation methods for kidney and liver Organogenesis 5: 105-112. Link: https://bit.ly/3fzeSAt 
4. Yılmaz M, Karakoç A (2015) Böbrek Naklinde Alıcı ve Donörlerin Değerlendirilmesi. Nefr Hem Der 31-38. Link: https://bit.ly/2YcLpXu

5. (2018) Guidelines for Living Donor Kidney Transplantation. Fourth Edition. BTS LDKT Guidelines $4^{\text {th }}$ Edition Consultation Draft British Transplantation Society. Link: https://bit.ly/2AMn0is

6. Saidi RF, Hejazii Kenari SK (2014) Challenges of Organ Shortage for Transplantation: Solutions and Opportunities. Int J Organ Transplant Med 5 : 87-96. Link: https://bit.ly/2Nazzqw

7. (2018) Organ Procurement and Transplantation Network (OPTN). 5.

8. Tuğmen C, Sert I, Gireniz Tatar B, Kebapcı E, Ölmez M, et al. (2016) Kadavra vericili böbrek naklinde donör kaynaklı Pseudomonas enfeksiyonu. Tepecik Eğit ve Araşt Hast Dergisi 26: 63-68. Link: https://bit.ly/30Q5nZP

9. Ari BE (2000) Posttransplant Enfeksiyon Profilaksisi Ve Aşılamalar Transplantasyon Nefrolojisi Pratik Uygulama Önerileri, Bölüm 11: 91-96.
10. Ciancio G, Mattiazzi A, Miller J, Burke GW (2003) Daclizumab as induction therapy in kidney and simultaneous pancreas-kidney transplantation. Minerva Urol Nefrol 55: 43-56. Link: https://bit.ly/30V6WFB

11. Özdemir D, Şencan I, Karabay O, Kurt H (2006) Solid Organ Transplant Alıcılarında Görülen İnfeksiyonlar ve Korunma, Flora infeksiyon Hastalıkları ve Mikrobiyoloji Dergisi. Link: https://bit.ly/2NbfHU9

12. Özdemir D, Şencan I, Karabay O, Kurt H (2006) Solid Organ Transplant Alıcılarında Görülen İnfeksiyonlar ve Korunma. Flora infeksiyon Hastalıkları ve Mikrobiyoloji Dergisi. Link: https://bit.ly/2NbfHU9

13. Stockfleth E, Nindl I, Sterry W, Ulrich C, Schmook T, et al. (2004) Human papillomaviruses in transplant associated skin cancers. Dermatol Surg 30: 604-609. Link: https://bit.ly/37DN6QG

\section{Discover a bigger Impact and Visibility of your article publication with}

\section{Peertechz Publications}

\section{Highlights}

* Signatory publisher of ORCID

* Signatory Publisher of DORA (San Francisco Declaration on Research Assessment)

- Articles archived in worlds' renowned service providers such as Portico, CNKI, AGRIS, TDNet, Base (Bielefeld University Library), CrossRef, Scilit, J-Gate etc

* Journals indexed in ICMJE, SHERPA/ROMEO, Google Scholar etc.

* OAI-PMH (Open Archives Initiative Protocol for Metadata Harvesting)

* Dedicated Editorial Board for every journal

* Accurate and rapid peer-review process

* Increased citations of published articles through promotions

* Reduced timeline for article publication

Submit your articles and experience a new surge in publication services (https://www.peertechz.com/submission).

Peertechz journals wishes everlasting success in your every endeavours.

Copyright: @ 2020 Yüzbaşıoğlu MF, et al. This is an open-access article distributed under the terms of the Creative Commons Attribution License, which permits unrestricted use, distribution, and reproduction in any medium, provided the original author and source are credited.

Citation: Yüzbaşıŏlu MF, Güzel H, Çelik GO, Tuna A, Benlier N, et al. (2020) Microbiological culture results and antibiotic sensitivity in renal preservation solution. Arch Clin Nephrol 6(1): 020-023. DOl: https://dx.doi.org/10.17352/acn.000042 